\title{
The influence of tectonics on petrological characteristics of anhydrite and anhydrite-halite intercalations in the Oldest Halite (Na1) (Zechstein, Upper Permian) of the Bądzów area (SW Poland)
}

\author{
Tomasz TOBOŁA ${ }^{1, \text { * }}$
}

1 AGH University of Science and Technology, Faculty of Geology, Geophysics and Environmental Protection, Al. A. Mickiewicza 30, 30-059 Kraków, Poland

Toboła, T., 2014. The influence of tectonics on petrological characteristics of anhydrite and anhydrite-halite intercalations in the Oldest Halite (Na1) (Zechstein, Upper Permian) of the Bądzów area (SW Poland). Geological Quarterly, 58 (3): 531-542, doi: $10.7306 / g q .1171$

The Oldest Halite (Na1) (Zechstein, Upper Permian) played a significant role in the development of geological structure of the Fore-Sudetic Monocline (SW Poland) because of its different rheological properties in comparison to the adjacent rocks. Intercalations of anhydrite and anhydrite-halite occurring within the Na1 show a lot of features of tectonically disturbed rocks. Macroscopic petrological observations revealed that anhydrite rocks represent four rock types with different structural and textural properties. On the microscopic scale, five types of crystals have been distinguished in all macroscopic types. They vary in size, shape and distribution of primary fluid inclusion assemblages. The anhydrite-halite rocks show two groups with slightly different petrological features that are apparently related to their tectonic deformation and recrystallisation processes. The main recorded directions of tectonic movements seem to be horizontal or sub-horizontal.

Key words: Fore-Sudetic Monocline, Zechstein, anhydrite, microtectonics, Oldest Halite (Na1).

\section{INTRODUCTION}

Discovery and then documentation of copper deposits in the Permian of the SW Fore-Sudetic Monocline (SW Poland) in the middle of the twentieth century led to extensive geological surveying of this area (Fig. 1). Numerous exploratory boreholes, geophysical researches and access to the Cu-deposit by mining openings as well as by other mining works in the Zechstein strata: Lower Anhydrite (A1d) and first of all the Oldest Halite (Na1), revealed that the geological setting of the area is much more complex than it had been assumed previously.

The different rheological properties of rock salts took important role in tectonic development of the whole area. The position of the Na1 between the rigid rocks occurring below and above (Fig. 2), weakened regional and local tectonic strain, damping the faults downward the basement and generating a separate block system in the cover (Markiewicz, 1999, 2003, 2004, $2007 a, b, c)$. These processes also controlled the structural and textural features of the salt rocks as well as observed tectonic disturbances such as folds, cracks, or occurrence of large halite crystals (Markiewicz, 2003, 2007c; Banaszak et al., 2007; Burliga, 2007; Toboła and Markiewicz, 2009).

\footnotetext{
*E-mail: tob@geolog.geol.agh.edu.pl
}

Received: April 15, 2013; accepted: March 12, 2014; first published online: May 23, 2014
The aim of this paper is to present petrological characteristics of anhydrite intercalations within the $\mathrm{Na} 1$; these intercalations are often accompanied by anhydrite-halite breccias in the Bądzów salt deposit (SW Poland; Fig. 1).

\section{GEOLOGICAL SETTING}

In the general outline of the LGOM (Lubin-Głogów Copper District), four main structural units were distinguished (Tokarski, 1958; Tomaszewski, 1963a, b): Fore-Sudetic Block, crystalline basement of the Fore-Sudetic Monocline, ForeSudetic Monocline, and Cenozoic cover of the Fore-Sudetic Block (Fig. 1). The Fore-Sudetic Block and crystalline basement consist of magmatic and metamorphic rocks. In turn, both the Fore-Sudetic Monocline and the Cenozoic cover are built of sedimentary rocks. The Fore-Sudetic Block is separated from the Fore-Sudetic Monocline and its basement by a deep regional dislocation (Middle Odra Dislocation Zone) (Oberc, 1967, 1972).

In the LGOM area, the Fore-Sudetic Monocline consists of Permian and Triassic sediments. The Permian is subdivided into terrigenous (Rotliegend) and marine (Zechstein) sediments. The Lower Rotliegend (Autunian) sediments consist of dark brown conglomerates and sandstones. At the top, they are covered by discontinuous series of volcanic eruptive rocks (rhyolite, melaphyre, basalt, pyroclastic rocks). The Upper Rotliegend (Saxonian) strata are well-developed in the western part of the Fore-Sudetic Monocline and they are composed 


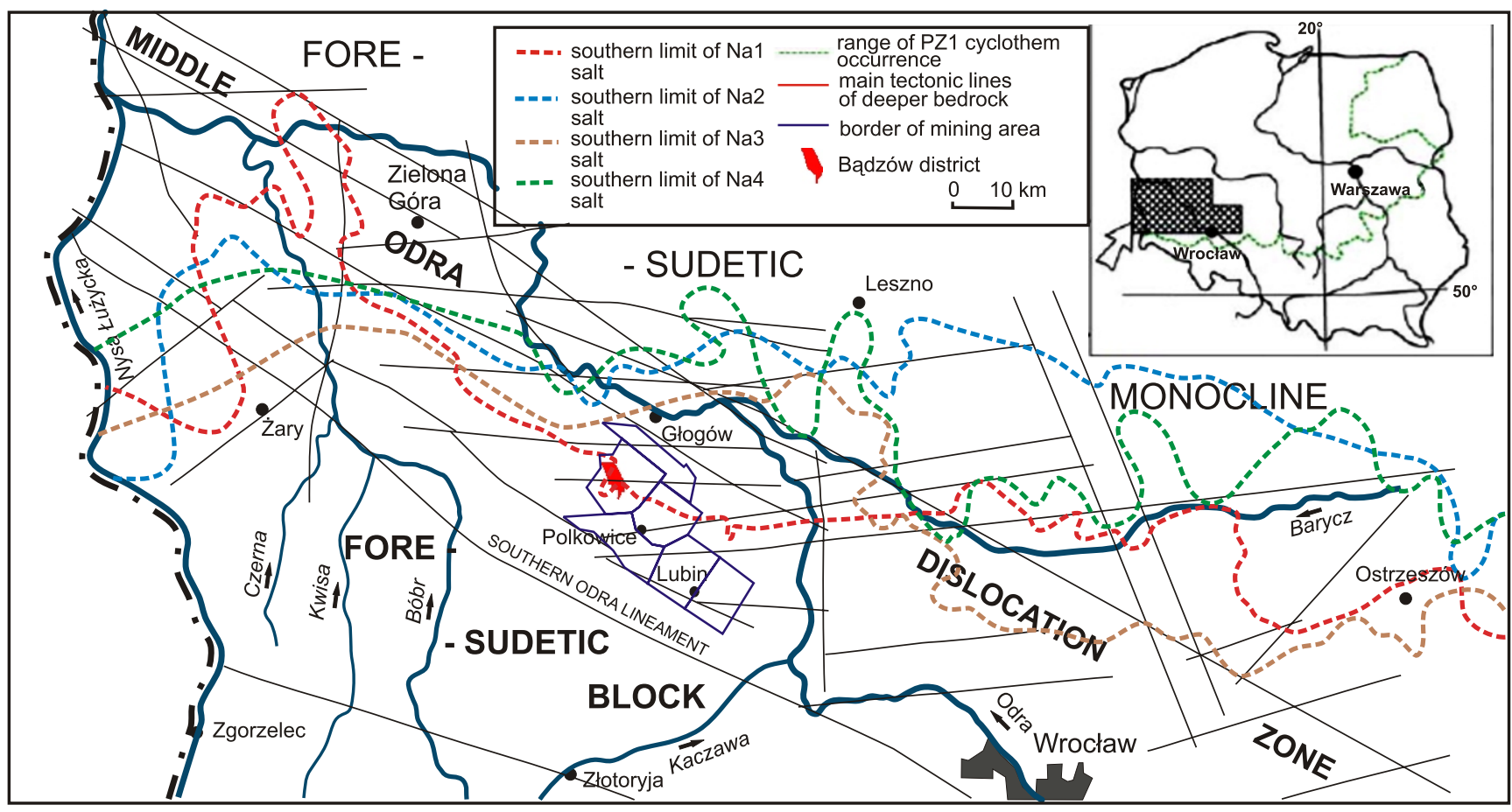

Fig. 1. Extent of Zechstein salts in the southern Fore-Sudetic Monocline (SW Poland) with location of the Bądzów area (after Markiewicz and Becker, 2009)

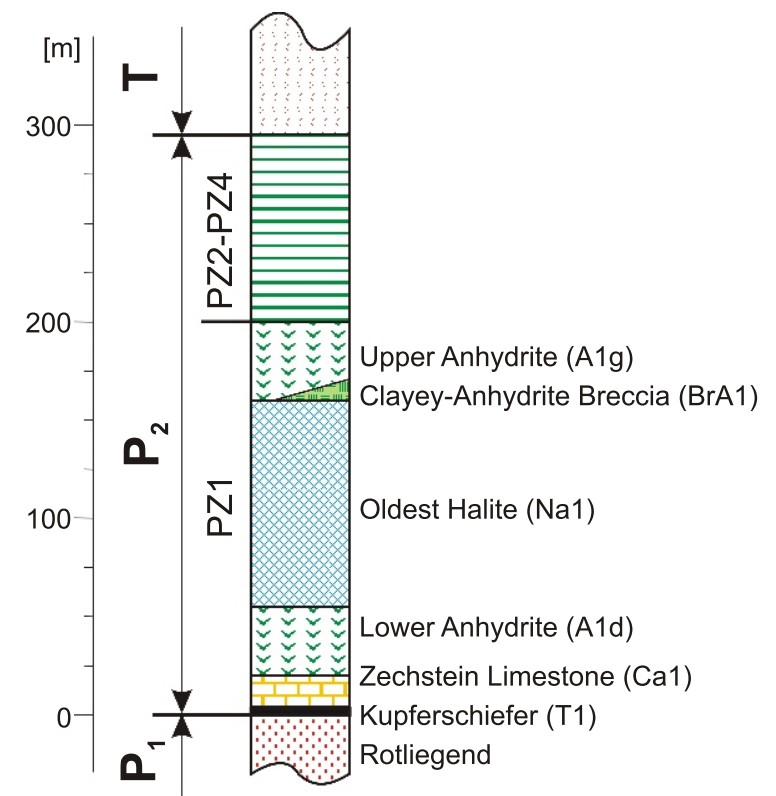

Fig. 2. Lithological profile of Zechstein sediments in the Fore-Sudetic Monocline

of red fine-grained and medium-grained sandstones and conglomerates (Kłapciński and Peryt, 2007 with references therein). The Rotliegend sediments are very often discoloured and developed as white or grey fine-grained sandstones near the boundary with the overlying Zechstein sediments (Peryt and Oszczepalski, 2007). They are overlain by the Kupferschiefer (T1) which forms the base of the Zechstein; it was deposited following the transgression of the Zechstein sea into the Southern Permian Basin some 258 Ma ago (see Peryt et al., 2012 with references therein).
As in other parts of the Zechstein basin, four evaporite cyclothems occur in the LGOM (Kłapciński, 1964a, b, 1966; Szybist, 1976; Peryt, 1981). The lowest cyclothem (PZ1) is fully developed in the area of Sieroszowice (Fig. 2). It has a great economic importance due to the copper ore and other metals (e.g., Kucha and Mayer, 2007; Nieć and Piestrzyński, 2007; Piestrzyński, 2007). The Na1 member occurs in the northern and NE parts of the LGOM area (Fig. 3). Toward the S and SW, it is pinching out and the member is replaced by clayeyanhydrite breccias (BrA1) that occur also at the boundary between the Na1 and A1g (e.g., Kłapciński, 1964a, b, 1966, 1971; Lorenc, 1975; Kijewski and Salski, 1978; Czapowski et al., 1993; Markiewicz, 2007a, c).

The Na1 of the LGOM area has been well-documented by numerous boreholes, mining openings and underground boreholes (Fig. 3; Szybist, 1976; Banaszak et al., 2007; Burliga, 2007; Markiewicz, 2007a, b, c; Markiewicz and Becker, 2009; Toboła and Markiewicz, 2009). The unit occurs in the southern and central parts of the Sieroszowice I Mining area where it forms an irregular bed of principal extension WNW-ESE and dips $3-8^{\circ}$ (locally $15^{\circ}$ ) towards the NE. The present limit of the $\mathrm{Na} 1$ in the western and southern parts of the area is irregular, exhibiting numerous highly elongated gulfs and separated patches of salts. The salt thickness varies from 0 to $186 \mathrm{~m}$ (Banaszak et al., 2007). This thickness variability resulted from the strongly diversified morphology of salt seam bottom and top (Szybist, 1976; Banaszak et al., 2007; Burliga, 2007; Markiewicz, 2007a, b, c).

The inner tectonics of the $\mathrm{Na} 1$ is very complicated. There are various types of folds, shear zones, flexures and fault zones, indicating large-scale salt movement (Szybist, 1976; Banaszak et al., 2007; Burliga, 2007; Markiewicz, 2007a, b, c). This "flow" of salt has contributed to the significant transformation of salts and their diversity in terms of petrological features.

The upper cyclothems (PZ2, PZ3 and PZ4) consist of alternating terrigenous, carbonate and sulphate deposits. They are covered by Triassic rocks (ca. $650 \mathrm{~m}$ thick) and then, discor- 


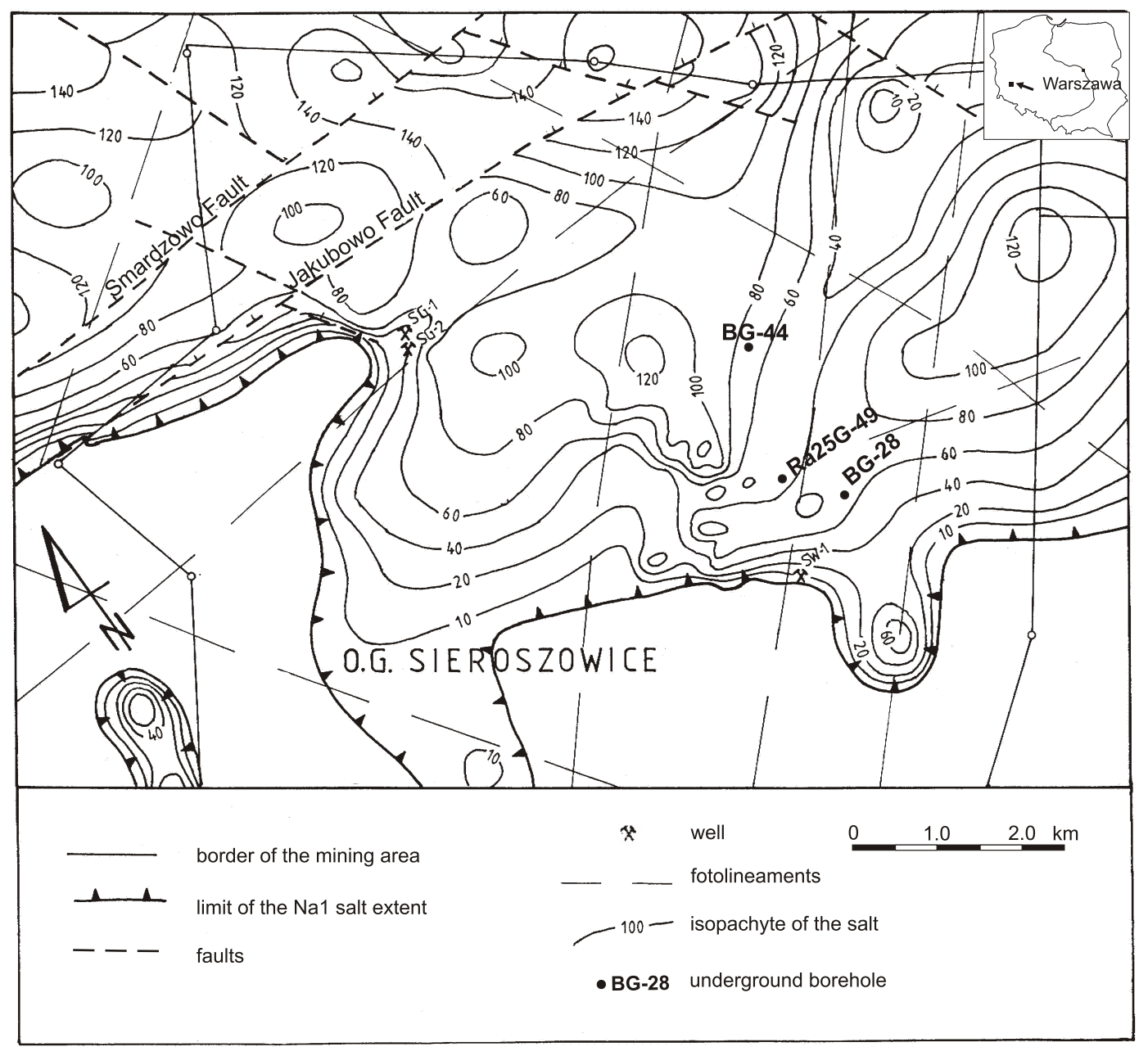

Fig. 3. Isopachous map of the Oldest Halite (Na1) in the Sieroszowice Mining area (after Banaszak et al., 2007)

dantly, by Cenozoic sediments. Their upper part is strongly disturbed by glaciotectonism.

The geological surveying of the LGOM area indicated the presence of two systems of faults in the basement of Zechstein deposits (Fig. 1; Salski, 1996; Markiewicz, 2007c). A system of NW-SE-trending faults dominates in the southern part. In the central part of the area, this system is accompanied by W-Eoriented faults. In the northern part, there is the third system of faults trending $\mathrm{N}-\mathrm{S}$.

\section{METHODS}

Petrological descriptions of the anhydrite intercalations and anhydrite-halite rocks and breccia from the Na1 of the Bądzów area ( $E$ part of the Sieroszowce salt deposit) were performed on 33 samples taken from drillcores of boreholes drilled in the mine openings (BG-44, BG-28, Ra25G-49 - Fig. 3). Microscopic studies were preceded by preliminary macroscopic analyses carried out on the surface of intersection and fresh fracture, using the stereo microscope of magnification from 5 to 50 times.

Microscopic studies were performed on standard thin sections ( $20 \mu \mathrm{m}$ thick) and thick sections $(0.5-2.0 \mathrm{~mm})$. The former were cut from pure anhydrite rocks without halite admixture. The latter were prepared from anhydrite-halite rocks, breccias and adjacent rock salts. Thickness of the thick sections depended on the sample transparency which was mainly related to the volume ratio between halite and anhydrite. These sections were obtained by cutting with a low-speed saw. In the next stage, they were ground with sandpaper and polished. Petrological observations of the thin and thick sections were performed on a Nicon Eclipse E600 microscope, using 5x, 20x, 50x and 100x magnification objectives. As an additional UV source, an outside diode lamp ( $365 \mathrm{~nm}$ ) was used.

\section{PETROLOGICAL CHARACTERISTICS OF ANHYDRITE}

The thickness of intercalations of anhydrite and anhydrite-halite (breccia) rocks is very variable - from several centimetres up to $17.1 \mathrm{~m}$ (Banaszak et al., 2007). The number and horizontal and vertical position of such intercalations are also variable. In the Bądzów Mining area, they occur mostly in the central and bottom parts of the salt profile. In the central part of the salt profile, they form lenticular, irregular, sometimes strongly bent, discontinuous layers that usually do not correlate between adjacent mining holes. More continuous anhydrite layers occur in the bottom part of the salt seam.

Macroscopic observation shows the presence of four main types of anhydrite rocks with respect to their petrological features: laminated, banded, lenticular and concretional, and structureless (Table 1), similar to those described by RichterBernburg (1955) or Forkner (2010). Occasional are rocks of 
A

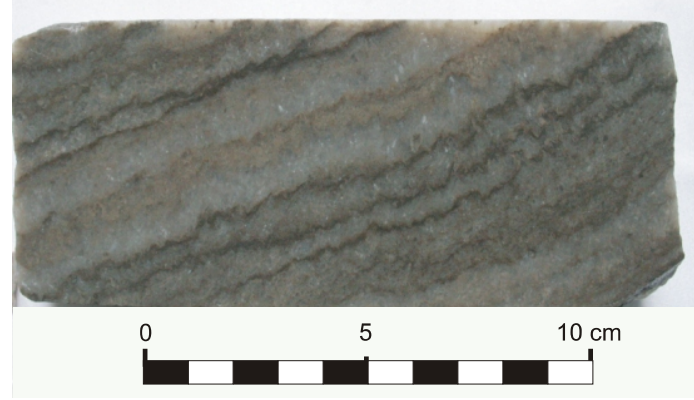

C
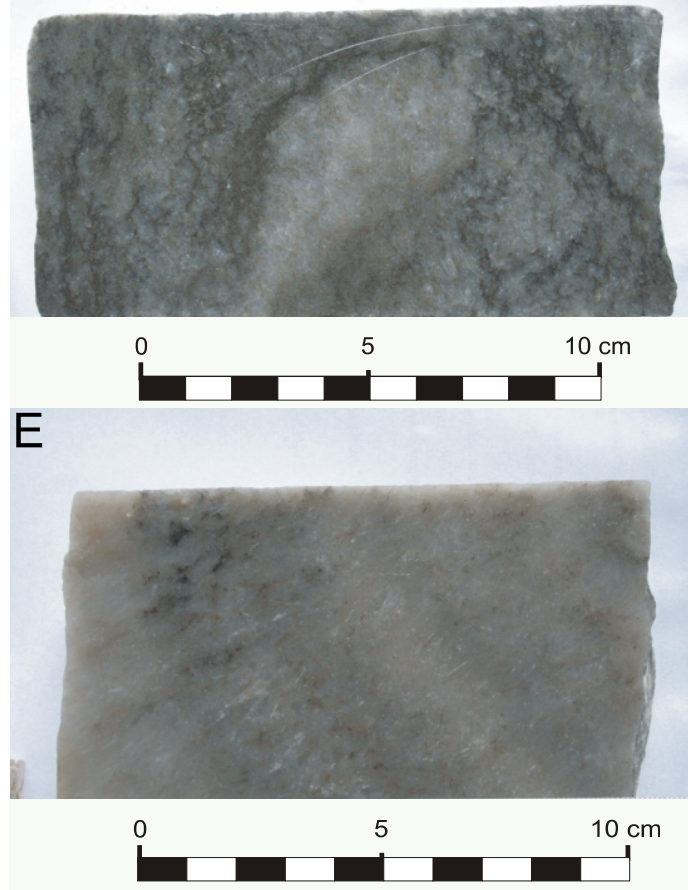

B

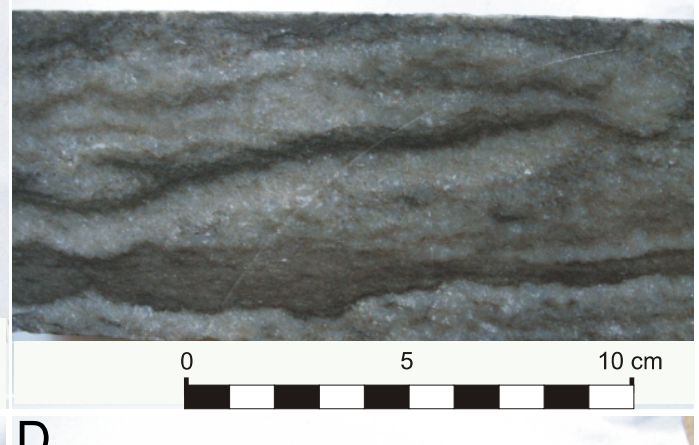

D
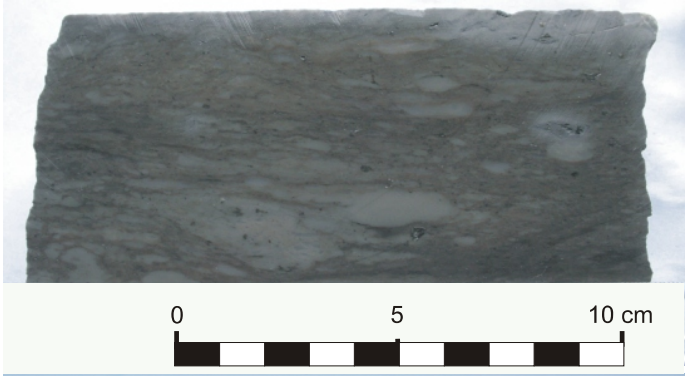

$\mathrm{F}$

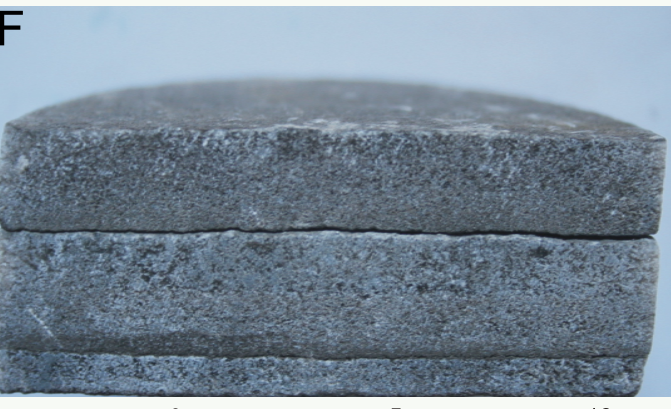

Fig. 4. Main macroscopic lithological types of anhydrite rocks

A - laminated anhydrite, B - banded anhydrite, C - concretional anhydrite, D - lenticular anhydrite, E - structureless anhydrite, F - shaly anhydrite

shaly structure. Rocks of intermediate features occur between them.

Five types of anhydrite crystals (I-V) have been distinguished (Table 2); with intermediate types between them. In laminated and banded anhydrite, there are all types of anhydrite crystals, with the most common types of II, III and IV. The crystal long axes (type II) are often arranged nearly parallel to each other, forming elongated streaks or fan-shaped, locally cloudy concentrations (see Fig. 6B). They are accompanied by type IV crystals. The fine-crystalline anhydrite mass (type III) is dispersed or forms small, irregular, slightly elongated concentrations (Fig. 5E) that rarely form discrete elongated streaks. The large crystals (type I) occur as single individuals chaotically distributed within the rock mass.

In the lenticular and concretional anhydrite, the lighter anhydrite concentrations are composed of type III or rarely type $\mathrm{V}$ crystals. The darker background also consists mainly of type III anhydrite crystals. Impurities are scarce within its area. They form very small lenses and irregular aggregates. The structureless anhydrite consists of type III anhydrite crystals with a small amount of type $V$ crystals which forms lenticular or more irregular concentrations.
Impurities are distributed unevenly. In some parts of the rocks corresponding to bright laminae, bands and lenses, impurities are lacking or extremely rare. Within the darker parts, they form different accumulation types. In all macroscopic types of rocks, except in the structureless anhydrite, they mostly form irregular wavy streaks, light brown to almost opaque in transmitted light (Fig. 6B). They consist of clay minerals probably with admixture of organic matter (bitumens). Less frequently, they form irregular aggregates, from several micrometres to about $0.5 \mathrm{~mm}$ in size (Fig. 6C). In this case, they are light brown in colour and very often they contain small (from a few to several micrometers in size) concentrations of opaque minerals. The lenticular anhydrite, in addition to the above-mentioned features, contains large (up to a few millimetres long) lenses, probably consisting of clay minerals with a small amount of randomly distributed opaque minerals (Fig. 6D), a few $\mu \mathrm{m}$ across. They are cracked and folded, showing the complicated inner structure built of smaller lenses or cloudy clusters elongated in the direction of the long axis of the whole lens. Some anhydrite samples also contain a minor amount of carbonate minerals. They form clusters, up to about $70 \mu \mathrm{m}$ in size (Fig. 6E), and consist of anhedral, rounded micrometric crystals. The larger clusters are 
Four main types of anhydrite rocks

\begin{tabular}{|c|c|}
\hline Rock type & Description \\
\hline Laminated & $\begin{array}{l}\text { Consists of light grey background with millimetric (up to } 3 \mathrm{~mm} \text { thick) laminae, dark grey to almost black or brown-grey in } \\
\text { colour (Fig. } 4 \mathrm{~A}) \text {. Their boundaries with the surrounding background are generally sharp. Such laminae occur at intervals of } \\
2-3 \mathrm{~mm} \text { to more than } 1 \mathrm{~cm} \text {, parallel to each other. They were very often small-scale folded, resembling stylolites. Some } \\
\text { samples show intense folding so that they lose their continuity and become very blurred over short distances. Lamination } \\
\text { is locally very gently disharmonically undulated and the laminae boundaries also become more blurred. }\end{array}$ \\
\hline Banded & $\begin{array}{l}\text { Generally has darker tint than laminated anhydrites. They consist of alternate bands of dark grey anhydrite, often with a } \\
\text { dark brown tinge alternating with light grey anhydrite, almost white, sometimes containing light brown matter (Fig. 4B). } \\
\text { Bands range from several millimetres to }>1 \mathrm{~cm} \text { in thickness. In general, their boundaries are sharp and clear. Similarly to } \\
\text { the laminated anhydrite, in the areas of disturbed bands, their boundaries become more diffuse. Very often the bands are } \\
\text { not uniform. Within both the darker and lighter bands one can observed a weakly evident botryoidal structure. It consists of } \\
\text { slightly brighter bunches than the background. In the darker bands, such clusters are up to } 1 \text { mm and occasionally to } 2 \mathrm{~mm} \\
\text { in size, and they are surrounded by a considerable amount of dark grey, often almost black matrix. In the brighter layers, } \\
\text { clusters are larger in size (to } 3-4 \mathrm{~mm} \text { ), and the surrounding matrix is usually light brown. }\end{array}$ \\
\hline $\begin{array}{l}\text { Lenticular } \\
\text { and } \\
\text { concretional }\end{array}$ & $\begin{array}{l}\text { Relatively heterogeneous group of rocks. They consists of lighter anhydrite aggregations inherent in darker anhydrite ma- } \\
\text { trix. The shapes of the concentrations are variable and change from irregular or slightly elongated (Fig. } 4 \mathrm{C} \text { ) to more elon- } \\
\text { gated and often lenticular (Fig. } 4 \mathrm{D} \text { ). In the first case, their outlines are generally fuzzy and pass continuously into the } \\
\text { matrix, only rarely they are sharply separated. The concentrations are usually from about } 1 \text { to } 7 \mathrm{~mm} \text {, rarely more than } 3 \mathrm{~cm} \\
\text { in size. In some cases, the rock matrix is somewhat similar to laminated anhydrite. This kind of rock display denser pack- } \\
\text { ing of millimetre-thick dark grey or almost black discontinuous and strongly folded laminaee. Elongated and lenticular } \\
\text { anhydrite clusters have very sharp and clear contours. Their characteristic feature is the position of the clusters, which that } \\
\text { always have the longer axes lying parallel to each other. Cluster size along the long axis is larger than in the case of more } \\
\text { isometric concentrations, and ranges from a few millimetres to about } 5 \mathrm{~cm} \text {. Less frequently, they are accompanied by } \\
\text { highly elongated lenses or small spherical concentrations of dark grey clay material. }\end{array}$ \\
\hline Structureless & $\begin{array}{l}\text { Uniformly developed on the macroscopic scale (Fig. 4E). They have usually light grey in colour with dark, brown or locally } \\
\text { black small and blurred spots or short streaks. The shaly-laminated anhydrite (Fig. 4F) on the macroscopic scale seems to } \\
\text { be a grey structureless rock. Under the impact, they breaks into a few millimetres thick plates. This feature is due to the min- } \\
\text { eral composition. Under the microscope, they consists mainly of anhydrite crystals accompanied by very small }(<1 \text { mm) ha- } \\
\text { lite crystals. In the individual laminae, the halite frequency of occurrence is variable, ranging from a few to several percent. }\end{array}$ \\
\hline
\end{tabular}

\section{Main features of anhydrite crystals}

\begin{tabular}{|c|c|c|c|c|}
\hline Type & Crystal size & Crystal shape & Crystal characteristics & Fluid inclusions \\
\hline I & $0.4-2.7 \mathrm{~mm}$ & $\begin{array}{l}\text { anhedral or less } \\
\text { often subhedral }\end{array}$ & $\begin{array}{l}\text { very often jagged and irregular boundaries; inner structure } \\
\text { not uniform; cracked and split into smaller parts, with indi- } \\
\text { vidual fragments somewhat displaced and twisted and ce- } \\
\text { mented with the clear anhydrite mass, giving an impression } \\
\text { of wavy or mosaic light extinction; } \\
\text { very seldom large anhydrite crystals not evidently cracked, } \\
\text { showing slightly arched cleavage surfaces and slightly } \\
\text { wavy light extinction; sometimes they do not show cleav- } \\
\text { age but they have solid ingrowths of clear anhydrite crys- } \\
\text { tals of euhedral faces with axes arranged differently than in } \\
\text { the host crystal (Fig. 5C) }\end{array}$ & $\begin{array}{l}\text { densely packed, very small } \\
\text { (ca. } 1 \mu \mathrm{m} \text {; Fig. } 5 \mathrm{~B} \text { ), occurring } \\
\text { only in the central parts of the } \\
\text { fragments, with their outer } \\
\text { parts being clear and free of } \\
\text { inclusions }\end{array}$ \\
\hline II & $\begin{array}{l}\text { long axes } \\
50-500 \mu \mathrm{m} ; \\
\text { a few to } 40 \mu \mathrm{m} \\
\text { in width }\end{array}$ & $\begin{array}{l}\text { subhedral or } \\
\text { almost euhedral; } \\
\text { highly elongated }\end{array}$ & $\begin{array}{c}\text { usually arranged with the long axis nearly parallel to each } \\
\text { other to form a wavy texture }\end{array}$ & $\begin{array}{l}\text { most of them show similar in- } \\
\text { clusion assemblages as type } \\
\mathrm{l} \text {, distributed in the central } \\
\text { parts of the crystals }\end{array}$ \\
\hline III & $\begin{array}{l}\text { from a few } \mu \mathrm{m} \\
\text { to } 30 \mu \mathrm{m}\end{array}$ & $\begin{array}{l}\text { anhedral, isomet- } \\
\text { ric, often rounded } \\
\text { or irregular }\end{array}$ & $\begin{array}{l}\text { form a dispersed binding agent for ot } \\
\text { of crystals, or sometimes constitut } \\
\text { accumulations or thin streaks (Fi }\end{array}$ & $\begin{array}{l}\text { without any primary fluid } \\
\text { inclusion assemblages }\end{array}$ \\
\hline IV & $\begin{array}{l}\text { from } \sim 50 \text { to a } \\
\text { few hundred } \mu \mathrm{m}\end{array}$ & $\begin{array}{l}\text { anhedral, slightly } \\
\text { elongated, } \\
\text { rounded corners }\end{array}$ & $\begin{array}{l}\text { often accompany types I and II or occur as single } \\
\text { crystals in the largest conglomeration of type III (Fig. } 5 F)\end{array}$ & $\begin{array}{l}\text { as in the case of types I and } \\
\text { II, they have fluid inclusions } \\
\text { assemblage in the middle } \\
\text { parts, while the outer parts } \\
\text { are clean }\end{array}$ \\
\hline V & $\begin{array}{l}\text { from } \sim 50 \text { to a } \\
\text { few hundred } \mu \mathrm{m}\end{array}$ & $\begin{array}{l}\text { subhedral to } \\
\text { euhedral (Fig. } 6 \mathrm{~A})\end{array}$ & similar to type IV but with more regular shapes (Fig. 6A) & contain no FIA \\
\hline
\end{tabular}

oval and very compact. The outer parts of some clusters contain presumed clay minerals. The smaller clusters are relatively loose and more irregular. Among the whole population of samples, there is one that displays different microscopic properties. It represents a lenticular type of anhydrite rocks, distinguished only by a slightly darker colouration. The matrix of the rock consists mainly of type III anhydrite crystals with a minor amount of type IV crystals. Its distinguishing feature is the presence of numerous clusters of carbonate minerals, in places composing up to $50 \%$ of the cluster volume, accompanied by the presence of opaque minerals (Fig. 6F). Thicker brown streaks, consisting probably of a mixture of clay minerals and bitumen, are also relatively frequent. Compared with the previously mentioned samples, concentrations of carbonate minerals in this unique sample are larger, reaching $0.2 \mathrm{~mm}$ in size, and their shapes are very irregular and blurred. They are often contaminated with brown clay substance. Opaque minerals form aggregates, from spherical to highly irregular in shape, and have ragged borders. Their sizes range from a few micrometers in the clayey-bitumen streaks to over $0.2 \mathrm{~mm}$ inside the anhydrite mass. The rock matrix contains lenses of pure anhydrite of type III or V (Fig. 6F). 

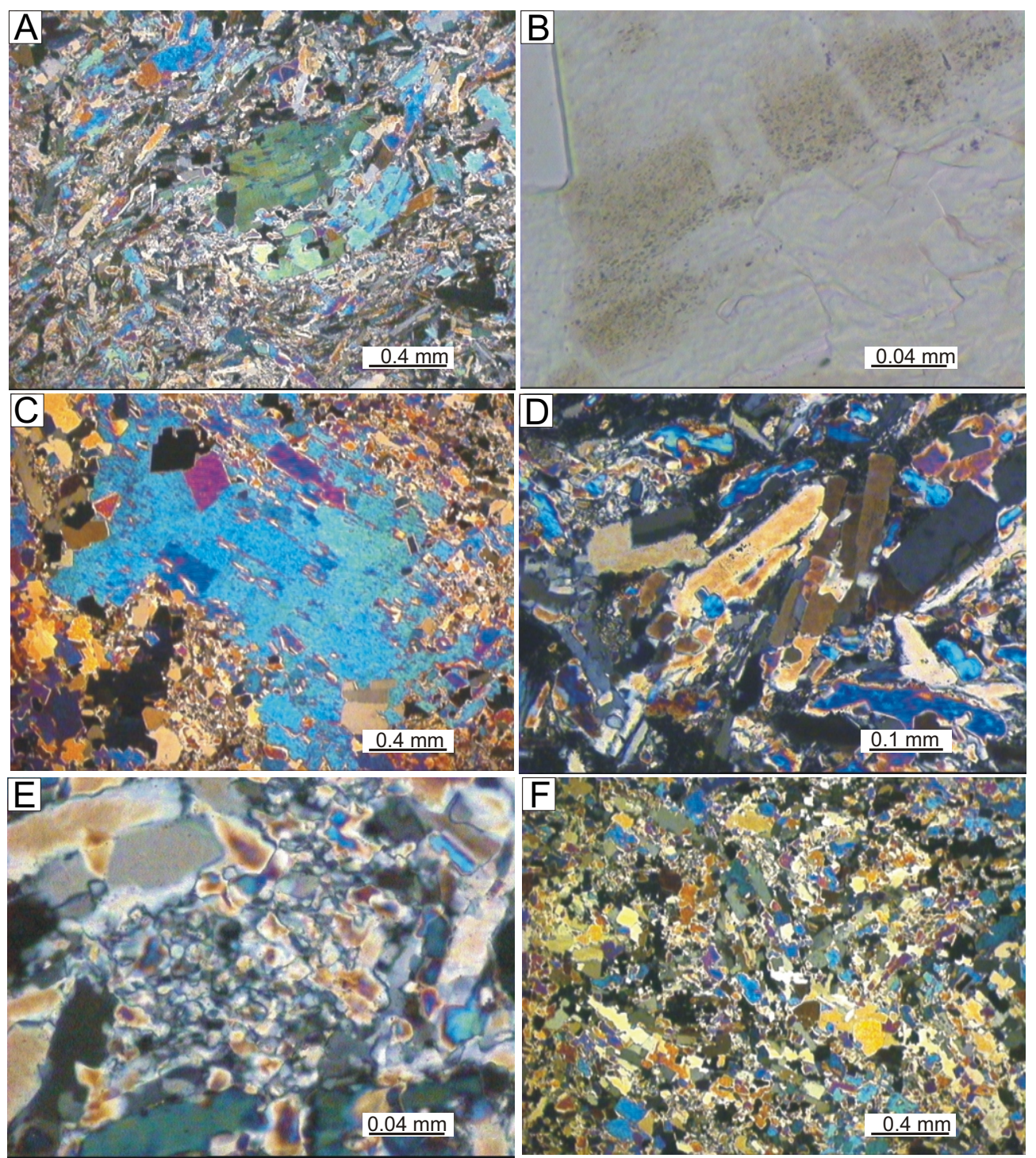

Fig. 5. Microscopic images in transmitted light

A - large and cracked anhydrite crystals of mosaic structure (type I) in other types of anhydrite crystals (crossed polarisers); B - distribution of the primary fluid inclusions assemblage (dark spots) in anhydrite crystal of type I (one polariser); C - large anhydrite crystal (type I; in the centre) without visible cracking planes but showing slight wavy light extinction and containing solid ingrowths of clear anhydrite crystals (crossed polarisers); D - concentrations of anhydrite crystals of type II (crossed polarisers); E - conglomeration of anhydrite crystals of type III (in the centre; crossed polarisers); F - conglomeration of anhydrite crystals of type IV (crossed polarisers)

\section{PETROLOGICAL CHARACTERISTICS OF ANHYDRITE-HALITE BRECCIAS}

In terms of petrological features, the anhydrite-halite rocks (breccias) form a very diverse group. Two basic types of such rocks were distinguished by the macroscopically observed different relation of anhydrite to halite. They are accompanied by layers of large-crystal salts (Fig. 7A) or tectonically changed halite (Fig. 7B).

The first rock type shows typical features of tectonic breccias (Fig. 7A, B). It consists of tight clusters of anhydrite, locally contaminated with clay minerals. These clusters are cemented by various types of halite, in places contaminated by finely dispersed anhydrite mass. The shape and size of the anhydrite clusters are variable. Their size ranges from about $1 \mathrm{~mm}$ to several centimetres, and the shape varies from angular, isometric, via elongated, lenticular (Fig. 7A) to very irregular, fuzzy, often with a wavy course (Fig. 7B). Some larger clusters with angular outlines show preserved primary lamination, blurred and slightly wavy in the microscopic images (Fig. 7C). This type of aggregates consists of relatively large anhydrite crystals (from dozen micrometers to about $0.2 \mathrm{~mm}$ in size).

Under the microscope, lenticular clusters consist of clean anhydrite which in comparison to that occurring in laminated crumbs, consists of smaller and more irregular in shape crystals (Fig. 7D). Larger lenticular clusters have a more complex inner structure visible also in macroscopic observations (Fig. 7A). They consist of small white or light grey lenses. Their long axes 

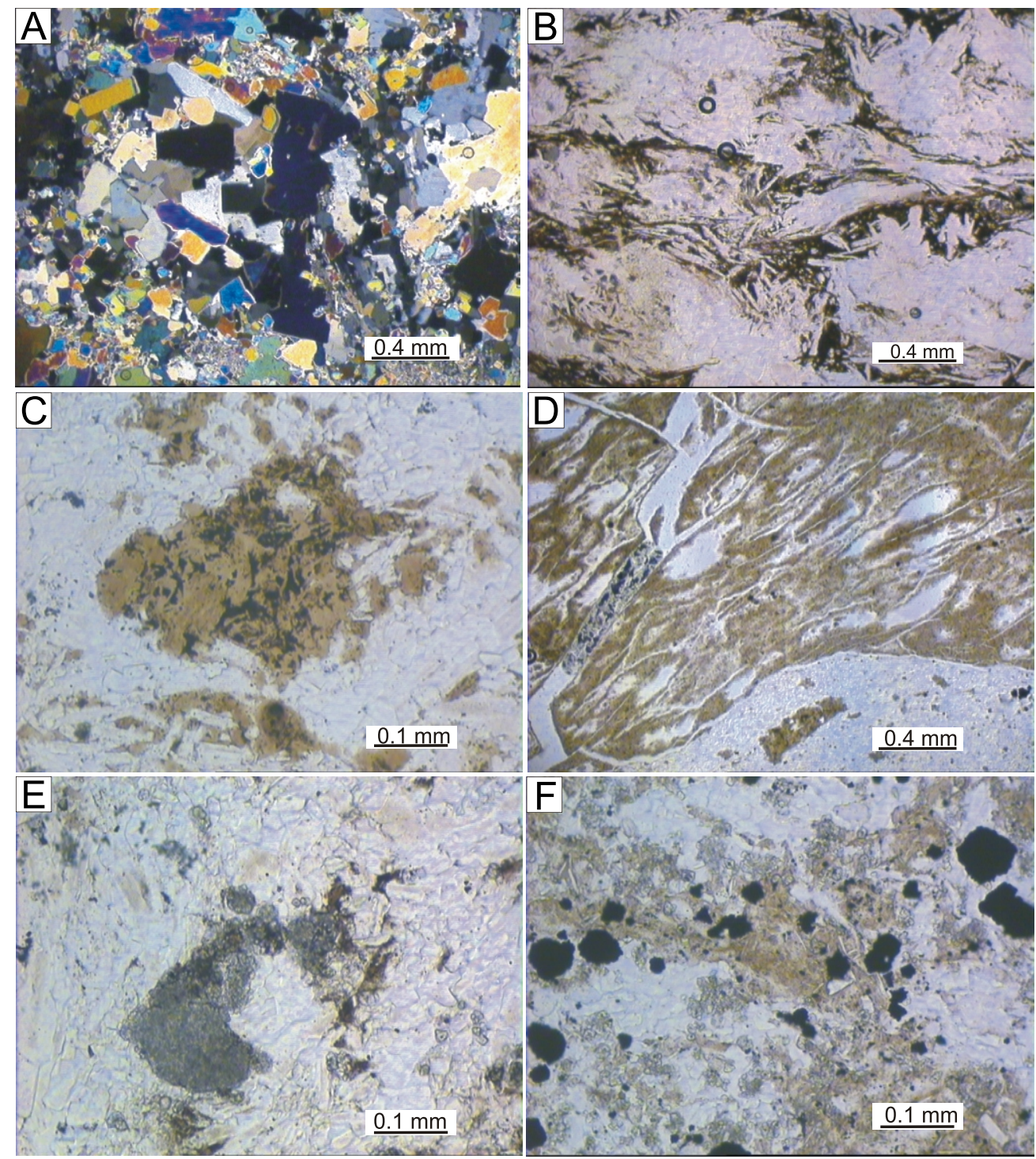

Fig. 6. Microscopic images in transmitted light

A - concentrations of anhydrite crystals of type $\mathrm{V}$ (in the centre; crossed polarisers); B - spatial arrangement of type II and IV anhydrite crystals (white) and admixture material (grey); contaminated bands of banded anhydrite (one polariser); C - irregular aggregates of admixture material (brown-grey) with opaque minerals (one polariser); D - part of a large lens of clay minerals with highly complicated inner structure (one polariser); E - concentrations of carbonate minerals (grey aggregates) in anhydrite rocks (white background), one polariser; $\mathbf{F}$ - anhydrite-carbonate rock contaminated by light brown matter and containing numerous opaque minerals (anhydrite - white, carbonate minerals - light grey)

are arranged parallel to each other and to the direction of the entire lenses. They are cemented by thin darker mass of anhydrite.

The irregular, fuzzy clusters are often highly elongated in one direction (Fig. 7B). Macroscopically and microscopically, they do not show any inner structure. The size of anhydrite crystals is smaller than in lenticular clusters and reaches a dozen micrometers.

The second type of the anhydrite-halite breccias (Fig. 8A) is structureless and massive, and does not show any spatial arrangement. In such rocks, anhydrite occurs as uniformly dispersed mass, accompanied by halite. Mutual quantitative relationships between anhydrite and halite are highly variable, ranging from rocks with predominant halite (anhydritic rock salt) to anhydrite rocks with single halite crystals.
Under the microscope, anhydrite crystals are anhedral, rarely subhedral, a few tens of micrometers to about $0.2 \mathrm{~mm}$ in size. These crystals are generally clean and transparent. Discontinuous, blurred and undulating streaks of dark brown substance are locally observed at their borders (Fig. 8B). Within the greater accumulation of anhydrite, very rare are large (up to $0.7 \mathrm{~mm}$ ) crystals. They have densely packed primary fluid inclusions associations (FIA) in the middle parts (Fig. $8 \mathrm{C}$ ), developed similarly as in the anhydrite crystals of type I or II.

The other (secondary) type of FIA commonly occurs in the parts of the rocks with prevalent anhydrite over halite (Fig. 8D). They are located on the borders of anhydrite or halite crystals. Their sizes vary from a few to several micrometers and the outlines are rounded, isometric, rarely more irregular. Locally, they 

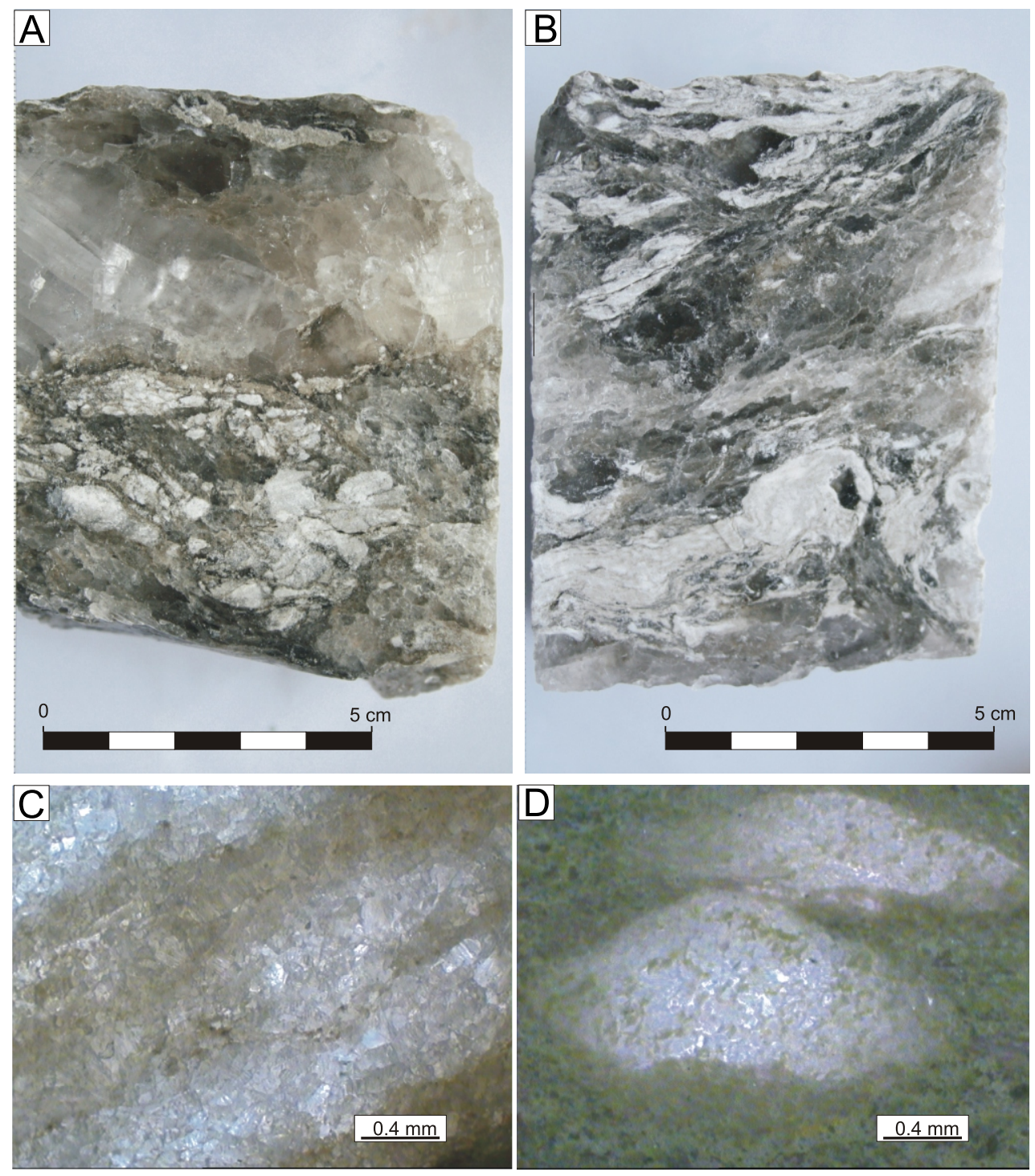

Fig. 7. Macroscopic and microscopic images of anhydrite-halite breccias

A - anhydrite-halite breccias with elongated and lenticular anhydrite clusters (white - in the lower part of image) and with coarse-grained halite intercalation (in the upper part of image); B - anhydrite-halite breccias with fuzzy, irregular anhydrite clusters (light grey) and with tectonicly changed halite (darker background); $\mathbf{C}$ - microscopic image of thick section in transmitted light of the angular anhydrite cluster; D - microscopic image of thick section in transmitted light of the small, clear anhydrite lenses (light) occurring in the larger anhydrite - clayey cluster (dark)

are connected together to form a network. They are filled predominantly by a gas phase.

In some parts of the samples, anhydrite also occurs in the form of small oval clusters (Fig. 8E). They appear mostly at the borders of halite crystals or within the areas of greater accumulation of anhydrite. In the last case, their occurrence is enhanced by the presence of a coating of light brown contaminating material.

At the borders of the anhydrite background and single halite crystals, there are also very large, even up to $>1 \mathrm{~mm}$ in size, anhydrite crystals (Fig. 9A). They are euhedral or subhedral, highly elongated in one direction and commonly with longer axes parallel to each other.

Halite appearing as cement for the crumbs of anhydrite, as well as creating various types of bands and a layer of rock salt occurring near breccia, has many features of tectonically recrystallised crystals (Toboła and Markiewicz, 2009). In general, they are mostly very clean and transparent. Contaminating material is very rare. In halite crystals located near the anhydrite crumbs, or in the second type of breccia, there are occasional cracks filled with dark brown substance, forming a rectangular network (Fig. 9B). In some halite crystals, isolated anhydrite ingrowths also occur. Their size ranges from a dozen micrometres to over $200 \mu \mathrm{m}$. Such anhydrite crystals display oval, elongated or less often tabular shapes. On their surfaces commonly show inclusions containing a concentration of brown substance (Fig. 9C). Locally, anhydrite ingrowths form aggregates consisting of loosely distributed crystals, arranged in elongated streaks. Most often they are arranged parallel to the borders of halite crystals. Such concentrations are accompanied by a variable amount of dark brown matter. 

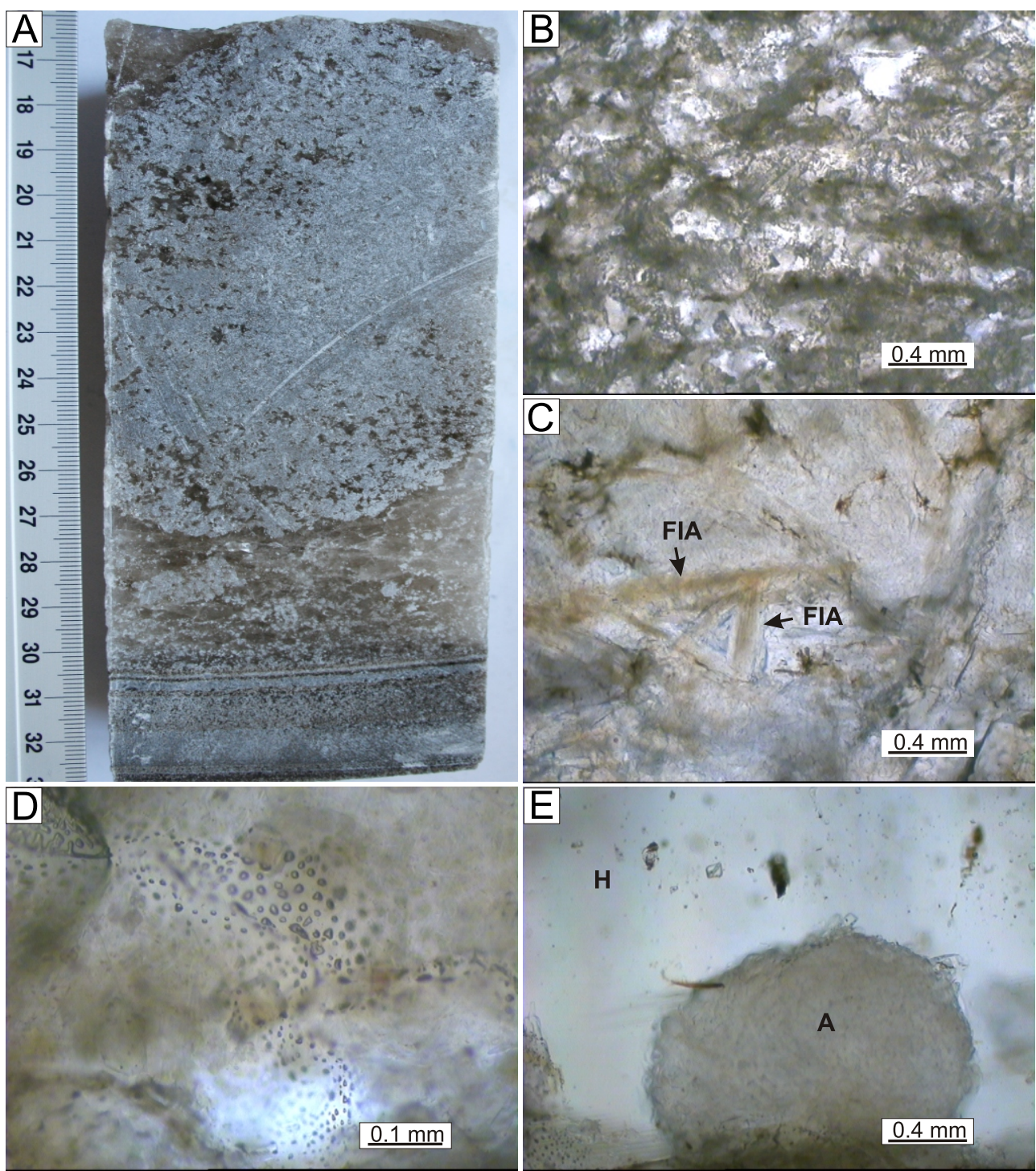

Fig. 8. Macroscopic and microscopic images of anhydrite-halite breccias

A - structureless anhydrite-halite breccias; B-E - microscopic images of thick section in transmitted light: B - distribution of impurities (dark) in anhydrite (light), C - larger anhydrite crystals with densely arrangement of primary fluid inclusions, $D$ - secondary fluid inclusions on the borders of anhydrite and halite crystals, E - cluster of anhydrite occurring on the border of larger halite crystal ( $\mathrm{A}$ - anhydrite, H - halite)

The larger halite crystals, in addition to anhydrite ingrowths, also occasionally contain FIA of the secondary type (Fig. 9D). In all the analysed samples of both types of the anhydrite-halite breccias, they strongly vary in development of shape and dimension. Most often they extend diagonally in relation to the crystal axis. Their courses are slightly wavy, curved, rarely straightforward and usually short, not covering the whole crystal. A characteristic feature of most of these assemblages is their way of disappearance within halite crystals. There is a gradual reduction in the size of inclusions towards their total disappearance. Most of the FIA are composed of small (several micrometres) inclusions, which are mainly liquid and regular or cubic in shape. Less common are larger inclusions with elongated shapes and the long axis of up to $200 \mu \mathrm{m}$. They are mostly liquid as well, but there are occasional two-phase inclusions with a very variable phase ratio.

A quite different type of FIA appears at the boundary of halite crystals (Fig. 9E). They also belong to the secondary inclusions, but their origin is not connected with cracking of the crystals. They are associated with the recrystallisation of halite crystals and migration of grain boundaries (den Brok et al., 1999; Passchier and Trouw, 2005; Toboła and Markiewicz, 2009). Their size ranges from a dozen $\mu \mathrm{m}$ to over $300 \mu \mathrm{m}$, and shapes are irregular, oval and considerably flattened. They are often connected to each other and form a dense network. Such inclusions are two-phase with a highly variable ratio of brines to gases, i.e., from liquid, through liquid-gas, to filled with gas phase only.

Occasionally in some larger halite crystals contain relics of primary FIA (Fig. 9F). They occupy the central parts of crystals in the form of irregular zones, while the outer part of crystals is clean. Such FIA consist of cubic inclusions filled only with brines, and are from several to a few tens of micrometers in size. Locally on the edge of these FIA zones, there are single large inclusions reaching $>1 \mathrm{~mm}$ (Fig. 9F). Their shapes are more irregular and more complex. They are composed of two phases, with ratio about $10 \%$ of gas volume. They commonly contain aggregates or single daughter minerals. 

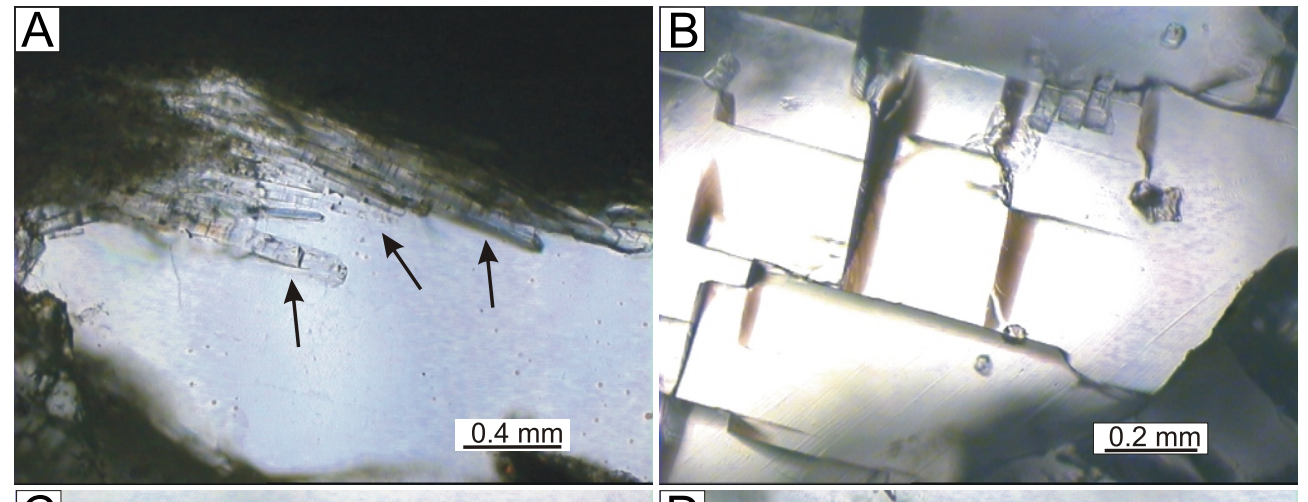

C
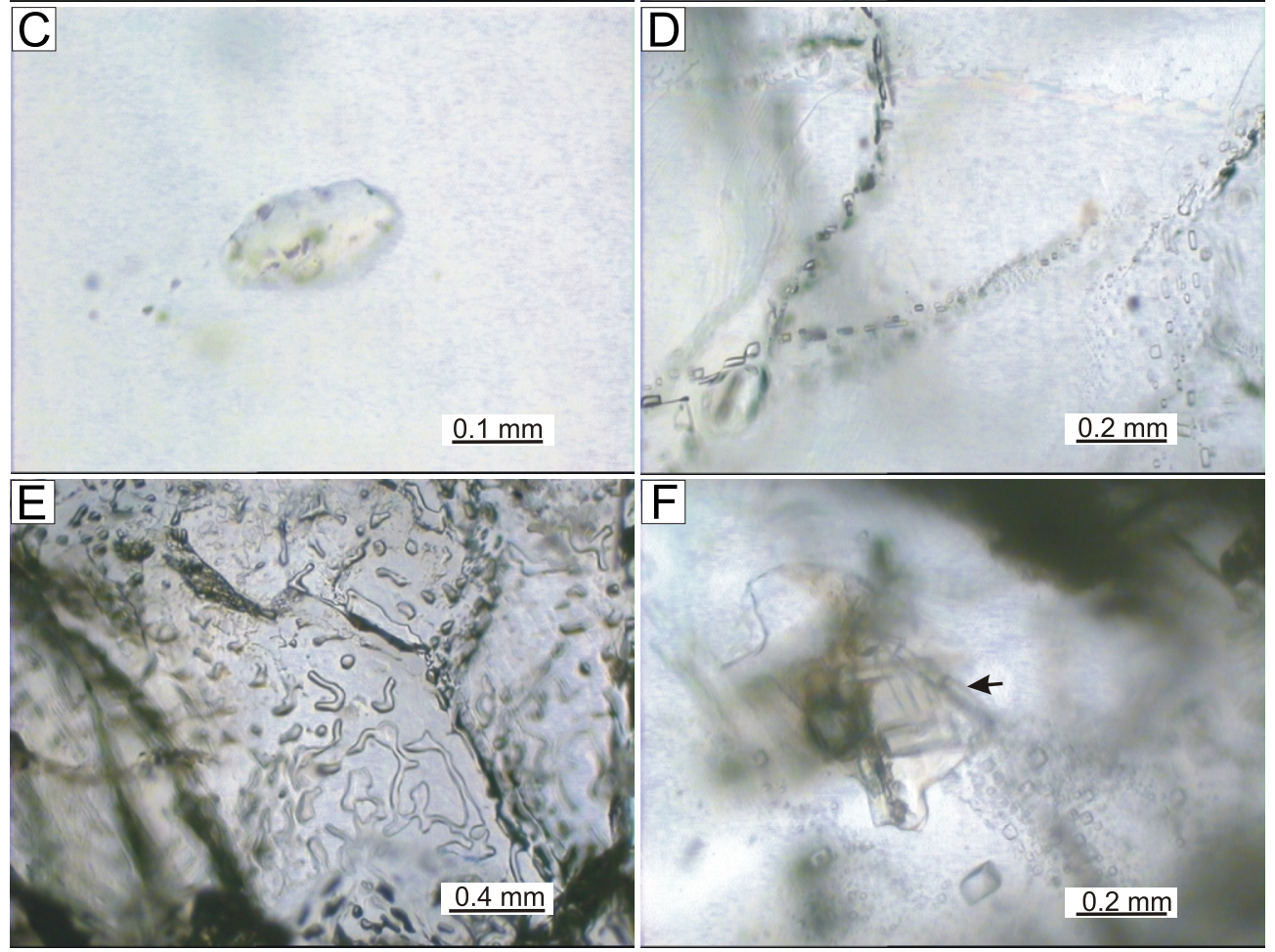

Fig. 9. Microscopic images of thick section in transmitted light

A - large anhydrite crystals (marked by arrows) ingrown in a halite crystal; B - cracks in halite crystals filled by dark brown mass; C - anhydrite ingrowth (in the centre) within the halite crystal containing inclusions of dark brown matter on its surface; $\mathbf{D}$ - examples of different kinds of secondary fluid inclusions in halite crystal; $\mathbf{E}$ - fluid inclusion assemblage located along halite boundaries; $\mathbf{F}$ - relicts of primary FIA in the centre part of halite crystal with one large inclusion containing daughter minerals (marked by arrow)

\section{DISCUSSION}

The petrological features of the anhydrite and anhydrite-halite breccias demonstrate varying degrees of tectonic deformation. With this regard, two groups of rocks may be distinguished. The first group includes laminated and banded anhydrites that have preserved their primary structures but their slight degree of tectonic deformation is evidenced by folded laminae and bands (Fig. 4A, B), often accompanied by blurred boundaries between bands or their hook bending, and disappearance of lamination, which may be the result of ductile deformation (cf. Passchier and Trouw, 2005). The anhydrite shows many features of recrystallisation or even epigenetic crystals (cf. Carozzi, 1960).

The co-occurrence of five types of anhydrite crystals and their spatial relationship could not be explained by sedimentary and diagenetic nature. It is rather the result of a strain in rocks and damage of the crystals. The large crystals (type I) seem to be relicts of relatively well-preserved primary crystals (Fig. 5A,
B). They are surrounded by the fine-grained mantle of type III crystals or wavy-arranged anhydrite crystals of type II or IV. Such an arrangement is similar to mantled porphyroclasts described from shear zones by Passchier and Trouw (2005). Their tectonic alteration is visible mainly by wavy light extinction or mosaic structure. The same primary origin can be accepted for type II and IV crystal, but these seem to be parts of large crystals that have been split up along the cleavage planes. This view is different from that presented by Lorenc (1975) for the Lower Anhydrite (A1d) and Upper Anhydrite (A1g) units, who accepted an epigenetic origin for large crystals. On the basis of the distribution of fluid inclusions that occupy the central parts of type I, II and IV crystals, it seems to be more probable that the core of the crystals represents its primary part. Densely packed FIA suggest rapid crystal growth in the sedimentary basin in favourable conditions (Roedder, 1984a, b; Goldstein and Reynolds, 1994; Goldstein, 2001). Such conditions may also be responsible for the formation of large crystals, if the number of nuclei of crystallisation was low. 
The outer, clear rim of such crystals is the result of other processes such as recrystallisation and grain boundary migration. The second process was stated in a low temperature regime for very soluble minerals such as halite (den Brok et al., 1999; Passchier and Trouw, 2005), but it may be assumed for less soluble minerals such as sulphates. The necessary mass of $\mathrm{Ca}^{2+}$ and $\mathrm{SO}_{4}^{2-}$ ions required for recrystallisation and growth of the rim originated from the very fine anhydrite mass formed during tectonic processes in shear zones. These processes also released a significant part of the solutions initially contained in inclusions. Such solutions played an important role and facilitated the recrystallisation. At a later time, as a result of stress caused by the overburden, remnants of primary crystals surrounded by the fine-grained anhydrite mass were subject to recrystallisation due to the migration of grain boundaries, resulting in the inclusion-free rim around the primary crystals. In places where the process did not take place, a very finely crystalline mass underwent slow recrystallisation to give small crystals of type III, or under more favourable conditions - of type $\mathrm{V}$. Therefore, in this context, type III and V anhydrite should be considered as epigenetic crystals.

The tectonic deformation of these rocks provides arrangement of elongated anhydrite crystals (type II), particularly wellvisible in the contaminated bands or laminae (Fig. 6B). Their parallel and wavy arrangement is similar to foliation observed in numerous deformed rocks. Moreover, the occurrence of rounded, S-shaped or sigmoidal aggregates of clear anhydrite with spiral arrangements of crystals indicates rotation of more coherent fragments (Fig. 6B) in more ductile matrix (e.g., Passchier and Trouw, 2005).

In turn, the second group of rocks consists of lenticular and concretionary anhydrites as well as anhydrite-halite breccia rocks of the first type with crumbs of anhydrite clearly showing significant tectonic disturbances on the macroscopic scale (Figs. 4C, D and 7A, B). The microscopic observations very well confirm the tectonic influence on rocks. The lenses and concentrations which are built of type III anhydrite crystals seem to be finely crushed the primary cleaner parts of anhydrite layers. They subsequently recrystallised, creating a more coherent fragments. The anhydritic mass that bound the lenses and concentrations also consists of type III of anhydrite crystals but with slightly higher contents of impurities forming microscopic lenses and elongated clusters. The presence of larger lenses composed of clayey material with very complex inner structure (Fig. 6D) confirms high tectonic disturbances, too.

The structureless anhydrites do not show obvious features of tectonic disturbances, but the lack of any type of lamination or bedding may indicate that these rocks underwent recrystallisation (Fig. 4E). They are built of fine-crystalline (type III) mass which may indicate that thicker layers of pure anhydrite rock were finely crushed (mylonitized).

In type I anhydrite-halite breccia, halite crystals also show many features of recrystallisation and the effect of grain boundary migration. This process is evidenced by, e.g., lack of primary FIA or the fact that their remnants are very rarely located in the centre of some halite crystals, by the presence of various types of secondary FIA (Fig. 9D) highlighting traces of healed fractures (e.g., Roedder, 1984a, b; Goldstein and Reynolds, 1994; Goldstein, 2001; van der Kerkhof and Hein, 2001; Kovalevych and Vovnyuk, 2010), and the presence of unhealed fractures (Fig. 9B). The occurrence of the characteristically developed inclusions on the borders of halite crystals (Fig. 9E) indicates a very advanced process of grain boundary migration (den Brok et al., 1999; Toboła and Markiewicz, 2009).
The same tectonic origin can be applied to the second type of anhydrite-halite breccia, where anhydrite and halite create a form of a mixture of random structure. These rock types were crushed and mixed and then recrystallised. The halite crystals also show the same features as in the first type of anhydrite-halite breccia. Recrystallised anhydrite crystals are also commonly observed.

It is worth noting that spatial arrangement of some elements, such as the extent of large halite crystals and tectonically changed salts, and the elongation of anhydrite clusters and lenses (and, on the microscopic scale, of smaller lenses of elongated anhydrite crystals of type II) in breccia, indicates that the tectonic movements display a nature of shear zones of horizontal or sub-horizontal distribution. Such arrangement, in combination with very strong recrystallisation, suggests that, in addition to the system of steeply dipping faults occurring in the basement and overburden sediments of the Na1 (e.g., Salski, 1996; Markiewicz, 2007a, b, c), horizontal tectonic movements played an important role. They had significantly affected the inner structure of the salt horizon (Burliga, 2007; Markiewicz, 2007a, b, c).

\section{CONCLUSIONS}

Anhydrite rocks and anhydrite-halite breccias occurring within the Oldest Halite (Na1) unit display very differentiated petrological features, which are largely due to the impact of tectonics and advanced processes of recrystallisation. Only some of the rocks show primary structures preserved.

In terms of tectonic deformation, the anhydrite rocks can be categorized macroscopically into two groups: (1) slightly deformed (laminated and banded anhydrite) with preserved primary structures, and (2) highly deformed (lenticular and banded anhydrites). The second group includes structureless anhydrite whose microscopic features indicate advanced tectonic disorder. Anhydrite-halite rocks are also subdivided into two main groups: rocks with preserved anhydrite crumbs and those more tectonically advanced with mixed mass of halite and anhydrite.

Anhydrite rocks consist of five types of crystals which differ with respect to size, shape and presence of primary FIA. The large crystals (type I) seem to be relics of primary minerals due to the occurrence of primary inclusions. They bear a signature of tectonic influence, manifested by wavy or mosaic light extinction. In general, the same origin should be inferred for types II and IV, however, these are parts of larger primary crystals which broke up under the tectonic stress. They also show intense recrystallisation manifested by the presence of a wide border around the primary core. On the contrary to these the fine-crystalline anhydrite mass (type III) and larger clear crystals (type V) should be considered as the secondary (epigenetic) origin indicating the shear zones.

Coexistence of such types of crystals, their mutual relations as well as intensity of occurrence in each type of macroscopically distinguished types of rocks very well confirm the tectonic deformation of the Oldest Halite strata and in particular an important role played by horizontal or sub-horizontal movements.

Acknowledgements. The study was supported by grant No. 10.10.140.320 from the AGH University of Science and Technology. The author would like to thank Prof. T. Peryt, Dr. S. $P$. Hryniv and an anonymous reviewer for their helpful comments and constructive criticism during the formulation and revision of this manuscript. J. Kubiak, M.Sc., and J. Wrzosek, M.Sc., from the KGHM are thanked for providing analytical material and thoughtful suggestions. 


\section{REFERENCES}

Banaszak, A., Garlicki, A., Markiewicz, A., 2007. Geology of the Oldest Rock Salt Kazimierzów in Sieroszowice I area (Polkowice-Sieroszowice Mine) (in Polish with English ). Gospodarka Surowcami Mineralnymi (Mineral Resources Management), 23 : 9-20.

Burliga, S., 2007. Internal structure of subhorizontal bedded rock salt formation in the area of Sieroszowice, SW Poland - mesoand microstructural indication (in Polish with English summary). Gospodarka Surowcami Mineralnymi (Mineral Resources Management), 23: 51-64.

Carozzi, A.V., 1960. Microscopic Sedimentary Petrography. John Wiley and Sons Inc. New York and London.

Czapowski, G., Peryt, T.M., Antonowicz, L., 1993. Facies and palaeogeography of the Zechstein (Upper Permian) Oldest Halite (Na1) in Poland. Bulletin of the Polish Academy of Sciences, Earth Sciences, 41: 217-227.

den Brok, B., Zahid, M., Passchier, C.W., 1999. Stress induced grain boundary migration in very soluble brittle salt. Journal of Structural Geology, 21: 147-151.

Forkner, R.M., 2010. An integrated system for macro-scale anhydrite classification. Geological Quarterly, 54 (4): 423-430.

Goldstein, R.H., 2001. Fluid inclusions in sedimentary and diagenetic systems. Lithos, 55: 159-193.

Goldstein, R.H., Reynolds, T.J., 1994. Systematics of fluid inclusions in diagenetic minerals. SEPM Short Course, 31: 1-199.

Kijewski, P., Salski, W., 1978. Zechstein rock-salt of the Z1 cyclothem in the south-western part of the Fore-Sudetic Monocline (in Polish with English summary). Geologia Sudetica, 13: 97-139.

Kłapciński, J., 1964a. Stratigraphy of the Zechstein in the areas of Lubin, Sieroszowice and Wschowa (in Polish with English summary). Rocznik Polskiego Towarzystwa Geologicznego, 34: 65-93.

Kłapciński, J., 1964b. Paleogeographical characteristics of the Zechstein of the Fore-Sudetic Monocline (in Polish with English summary). Rocznik Polskiego Towarzystwa Geologicznego, 34: 551-577.

Kłapciński, J., 1966. Stratigraphy of the Werra-Anhydrites in the region of Lubin and Sieroszowice (Lower Silesia) (in Polish with English summary). Rocznik Polskiego Towarzystwa Geologicznego, 36: 65-78.

Kłapciński, J., 1971. Lithology, fauna, stratigraphy and paleogeography of the Permian in the Fore-Sudetic Monocline (in Polish with English summary). Geologia Sudetica, 5: 77-135.

Kłapciński, J., Peryt, T.M., 2007. Budowa geologiczna monokliny przedsudeckiej (in Polish). In: Monografia KGHM Polska Miedź S.A. (ed. A. Piestrzyński): 108-115, Lubin.

Kovalevych, V., Vovnyuk, S., 2010. Fluid inclusions in halite from marine salt deposits: are they real micro-droplets of ancient seawater? Geological Quarterly, 54 (4): 401-410.

Kucha, H., Mayer, W., 2007. Geochemia (in Polish). In: Monografia KGHM Polska Miedź S.A. (ed. A. Piestrzyński): 197-207. Lubin.

Lorenc, S., 1975. Petrography and facies differentiation in the Werra Limestones and anhydrite rocks, Fore-Sudetic Monocline, SW Poland (in Polish with English summary). Geologia Sudetica, 10: 59-104.

Markiewicz, A., 1999. Neotectonic base of Quaternary fossil troughs of Middle Odra region (SW Poland) (in Polish with English abstract). Przegląd Geologiczny, 47: 825-830.

Markiewicz, A., 2003. Tektonika cechsztyńskiej soli kamiennej w LGOM i jej znaczenie dla działalności gospodarczej (in Polish). Ph.D. thesis. Arch. AGH, Kraków.
Markiewicz, A., 2004. Morphotectonics of the Odra Valley between Chobienia and Nowa Sól (Middle Odra region) (in Polish). Przegląd Geologiczny, 52: 1077-1078.

Markiewcz, A., 2007a. Thin-skinned structure of the south of Foresudetic Monocline vs. management of Na1 salt (in Polish with English abstract). Gospodarka Surowcami Mineralnymi (Mineral Resources Management), 23: 35-49.

Markiewicz, A., 2007b. Surveying the tectonics of the LubinSieroszowice deposit during its management (in Polish with English summary). Biuletyn Państwowego Instytutu Geologicznego, 423: 151-172.

Markiewicz, A., 2007c. Tektonika obszaru złoża (in Polish). In: Monografia KGHM Polska Miedź S.A. (ed. A. Piestrzyński): 115-132. Lubin,

Markiewicz, A., Becker, R., 2009. The original extent of the Oldest Halite (Na1) in the southern part of the Fore-Sudetic Monocline (SW Poland). Kwartalnik AGH Geologia, 35: 327-348.

Nieć, M., Piestrzyński, A., 2007. Forma i budowa złoża (in Polish). In: Monografia KGHM Polska Miedź S.A. (ed. A. Piestrzyński): 157-167. Lubin.

Oberc, J., 1967. Tectonic structure of the area of the XL Meeting of the Polish Geological Society (at Zgorzelec) (in Polish with English summary). Przegląd Geologiczny, 15: 253-261.

Oberc, J., 1972. Sudety i obszary przyległe (in Polish). In: Budowa geologiczna Polski. T. IV Tektonika, 2. Wyd. Geol. Warszawa.

Passchier, C.W., Trouw, R.A.J., 2005. Microtectonics. SpringerVerlag, Berlin Heidelberg.

Peryt, T.M., 1981. Zechstein in the neighbourhood of the ForeSudetic Block (in Polish with English summary). Kwartalnik Geologiczny, 25 (1): 75-91.

Peryt, T.M., Oszczepalski, S., 2007. Stratygrafia serii złożowej (in Polish). In: Monografia KGHM Polska Miedź S.A. (ed. A. Piestrzyński): 108-115. Lubin.

Peryt, T.M., Durakiewicz, T., Kotarba, M.J., Oszczepalski, S., Peryt, D., 2012. Carbon isotope stratigraphy of the basal Zechstein (Lopingian) strata in Northern Poland. Geological Quarterly, 56 (2): 285-298.

Piestrzyński, A., 2007. Okruszcowanie (in Polish). In: Monografia KGHM Polska Miedź S.A. (ed. A. Piestrzyński): 167-197. Lubin.

Richter-Bernburg, G., 1955. Über salinare Sedimentation. Zeitjschrift der Deutschen Geologischen Gesellschaft, 105: 593-645.

Roedder, E., 1984a. Fluid inclusions. Reviews in Mineralogy, 12.

Roedder, E., 1984b. The fluid in salt. American Mineralogist, 69: 413-439.

Salski, W., 1996. Tektonika złoża (in Polish). In: Monografia KGHM Polska Miedź S.A. (ed. A. Piestrzyński): 141-155. Lubin.

Szybist, A., 1976. Rock salt deposit in the Legnica-Głogów Copper Basin (in Polish with English summary). Przegląd Geologiczny, 24: 572-576.

Toboła, T., Markiewicz, A., 2009. Fluid inlusions in Oldest Halite (Na1) in Głogów area (SW Poland) - preliminary results (in Polish with English summary). Kwartalnik AGH Geologia, 35: 349-371.

Tokarski, A., 1958. Mogilno 1 - exploratory drilling problem (in Polish). Nafta, 14: 4-12.

Tomaszewski, J., 1963a. Budowa geologiczna obszaru między Lublinem a Sieroszowicami (Dolny Ślask) (in Polish). Ph.D. thesis. Arch. Instytutu Geol. Uniwersytetu Wrocławskiego. Wrocław.

Tomaszewski, J., 1963b. Tektonika brzeżnej części monokliny przedsudeckiej. Rudy i Metale Nieżelazne, 8: 207-210.

Van der Kerkhof, A.M., Hein, U.F., 2001. Fluid inclusion petrography. Lithos, 55: 27-47. 